\title{
Upaya Meningkatkan Hasil Belajar Siswa Melalui Penerapan Metode Pembelajaran Jigsaw Berbantuan Modul pada Siswa SMA Negeri 2 Labuapi
}

\author{
Aspari \\ SMA Negeri 2 Labuapi, Kabupaten Lombok Barat \\ Corresponding Author. Email: aspari1979@gmail.com
}

\begin{abstract}
This study aims to improve student learning outcomes by using the Jigsaw learning method assisted by the hydrocarbon material module. This research is a classroom action research which consists of two cycles. Each cycle consists of planning the action, implementing the action, observing and reflecting. The subjects of this study were students of class XI MIPA 1 SMA Negeri 2 Labuapi. The data sources came from teachers and students. Data obtained through interviews, observation, tests, and questionnaires. The data analysis technique used is descriptive qualitative and quantitative analysis. The results showed that the module-assisted Jigsaw learning method could improve: (1) student learning outcomes in cognitive aspects from $41.5 \%$ in cycle I to $72.3 \%$ in cycle II and in affective aspects from $68.92 \%$ in cycle I to $77.56 \%$ in cycle II. The conclusion of this research is that the use of the module-assisted Jigsaw learning method can improve student learning outcomes on the subject matter of hydrocarbons in class XI MIPA 1 SMA Negeri 2 Labuapi.
\end{abstract}

\begin{abstract}
Abstrak: Penelitian ini bertujuan untuk meningkatkan hasil belajar siswa dengan menggunakan metode pembelajaran Jigsaw berbantuan modul materi hidrokarbon. Penelitian ini merupakan penelitian tindakan kelas yang terdiri dari dua siklus. Setiap siklus terdiri dari perencanaan tindakan, pelaksanaan tindakan, observasi dan refleksi. Subyek penelitian ini adalah siswa kelas XI MIPA 1 SMA Negeri 2 Labuapi. Sumber data berasal dari guru dan siswa. Data diperoleh melalui wawancara, observasi, tes, dan angket. Teknik analisis data yang digunakan adalah analisis deskriptif kualitatif dan kuantitatif. Hasil penelitian menunjukkan bahwa metode pembelajaran Jigsaw berbantuan modul dapat meningkatkan: (1) hasil belajar siswa pada aspek kognitif dari 41,5\% pada siklus I menjadi 72,3\% pada siklus II dan pada aspek afektif dari 68,92\% pada siklus I menjadi $77,56 \%$ pada siklus II. Kesimpulan penelitian ini adalah penggunaan metode pembelajaran Jigsaw berbantuan modul dapat meningkatkan hasil belajar siswa pada materi pokok hidrokarbon kelas XI MIPA 1 SMA Negeri 2 Labuapi.
\end{abstract}

Key Words:

Learning Outcomes, Jigsaw, Module.

Kata Kunci:

Hasil Belajar, Jigsaw, Modul.

How to Cite: Aspari, A. (2020). Upaya Meningkatkan Hasil Belajar Siswa Melalui Penerapan Metode Pembelajaran Jigsaw Berbantuan Modul pada Siswa SMA Negeri 2 Labuapi. Jurnal Teknologi Pendidikan, 5(2), 126-131. Retrieved from http://ojs.ikipmataram.ac.id/index.php/jtp/article/view/3058

\section{Pendahuluan}

Di era globalisisasi saat ini dalam bebrbagai bidang kehidupan dituntut kualitas yang tinggi. Salah satu hal yang diperlukan agar dapat mempertahankan eksistensi adalah meningkatkan kualitas SDM yang dapat dicapai melalui pendidikan.Upaya peningkatan SDM itu dilakukan oleh pemerintah dengan melakukan perubahan-perubahan dalam kurikulum. Kurikulum yang diterapkan sekarang adalah kurikulum 2013. Kurikulum ini menekankan pada ketrlibatan siswa siswa selama proses pembelajaran.

Pembelajaran adalah membelajarkan siswa menggunakan asas pendidikan maupun teori belajar merupakan penentu utama keberhasilan pendidikan. Pembelajaran merupakan proses komunikasi dua ara, megajar dilakukan oleh guru sebagai pendidik, sedangkan belajar 
dilakukan oleh peserta didik atau siswa (sagala, 2009). Dalam belajar sangat dibutuhkan adanya aktivitas, dikarenakan tanpa adanya aktivitas proses belajar tidak mungkin berlangsung dengan baik. Pada proses aktivitas pembelajaran harus melibatkan seluruh aspek peserta didik, baik jasmani maupun rohani sehingga perubahan perilakunya dapat berubah dengan cepat, tepat, mudah dan benar, baik berkaitan dengan aspek kognitif afektif maupun psikomotor (Hanifah dalam Fajuri, 2019; Asni, 2017; Pratini, 2015; Nashirotum, 2020)

Kimia merupakan salah satu mata pelajaran wajib untuk kelas XI pada Kurikulum 2013. Pada saat in, kimia masih dianggap pelajaran yang menakutkan oleh sebagian orang dan tidak sedikit siswa yang mengalami kesulitan belajar pada mata pelajaran kimia. Salah satu materi yang dianggap sulit oleh siswa kelas XI MIPA adalah materi hidrokarbon. Materi ini membutuhkan pemahaman konsep yang kuat. Pada materi hidrokarbon siswa diharapkan dapat mengenal senyawa hidrokarbon, tata nama senyawa hidrokarbon, isomer dan sifat dan kegunaan senyawa hidrokarbon dalam kehidupan sehari-hari.

SMAN 2 Labuapi adalah salah satu sekolah di Kabupaten Lombok Barat yang menerapkan Kurikulum 2013,namun guru masih menerapkan metode konvensional dalam pembelajaran, sehingga pembelajaran masih berpusat pada guru (teacher centered learning). Hal ini berakibat hasil belajar kimia khususnya pada materi hidrokarbon rendah. Dari hasil observasi lapangan melalui wawancara dengan guru mata pelajaran kimia disampaikan bahwa pemahaman siswa terhadap materi hidrokarbon paling rendah dibandingkan materi yang lain pada semester 1 . Ketuntasan materi ini hanya sebesar 50\%. Dari hasil wawancara tersebut juga disampaikan bahwa metode yang digunakan dalam proses pembelajaran kimia yaitu ceramah karena tidak menyita banyak waktu akan tetapi metode ini kurang efektif dalam memicu aktivitas siswa serta menyebabkan kebosanan pada diri siswa.

Selain itu, dalam kegiatan belajar mengajar, interaksi guru dan siswa dalam proses belajar masih berjalan satu arah, yakni dari guru saja. Penyampaian materi menggunakan metode ceramah. Tidak ada kegiatan diskusi di kelas, sehingga aktivitas siswa terbatas pada mencatat penjelasan guru, mengerjakan tugas dari guru dan sesekali menjawab pertanyaan guru bila ditunjuk. Dari hasil ulangan harian pada tahun sebelumnya menunjukkan bahwa pemahaman siswa terhadap materi hidrokarbon cukup rendah dibandingkan materi yang lain pada semester 1 . Ketuntasan materi ini hanya sebesar $50 \%$.Dari hasil wawancara tersebut juga disampaikan bahwa metode yang digunakan dalam proses pembelajaran kimia yaitu ceramah karena tidak menyita banyak waktu akan tetapi metode ini kurang efektif dalam memicu aktivitas siswa serta menyebabkan kebosanan pada diri siswa. Berdasarkan data tersebut diatas, jika keadaan ini dibiarkan akan berdampak buruk bagi siswa sehingga diperlukan adanya perbaikan kualitas proses pembelajaran melalui pemilihan metode pembelajaran agar aktivitas dan hasil belajar siswa dapat ditingkatkan.

Jigsaw berbantuan modul yang merupakan pembelajaran Cooperative Learning. Metode Jigsaw dikembangkan dan diuji oleh Elliot Aronson dan rekan-rekan sejawatnya. Pada metode Jigsaw siswa-siswa ditempatkan pada kelompok-kelompok belajar heterogen beranggota tiga sampai enam orang (kelompok asal). Berbagai materi disajikan kepada siswa dalam bentuk teks dan setiap siswa bertanggung jawab untuk mempelajari satu porsi materinya. Selanjutnya para anggota dari kelompok-kelompok yang berbeda tetapi membicarakan topik yang sama (kelompok ahli) bertemu untuk belajar dan saling membantu dalam mempelajari topik tersebut. Kemudian siswa kembali ke kelompok asalnya dan mengajarkan materi yang telah mereka pelajari dalam kelompok ahli kepada anggotaanggotanya di kelompok asal. Setelah pertemuan dan diskusi pada kelompok asal selesai, siswa mengerjakan kuis secara individu tentang berbagai materi yang telah dipelajari. Dalam 
hal ini peran pendidik hanya sebagai fasilitator dan mediator dalam proes belajar mengajar. Pendidik cukup menciptakan kondisi lingkungan belajar yang kondusif bagi peserta didiknya (Haetami, 2010).

Pembelajaran Jigsaw bersifat kontruktivis, dimana siswa dituntut untuk membangun pengetahuan sendiri sehingga aktivitas dalam pembelajaran menjadi student centered learning. Menurut Adriani dan Andi Prastowo (2014) dalam proses pembelajaran modul digunakan sebagai penyedia informasi dasar, karena dalam modul disajikan berbagai materi pokok yang masih bisa dikembangkan lebih lanjut; sebagai bahan intruksi atau petunjuk bagi peserta didik; serta sebagai bahan pelengkap dengan ilustrasi dan foto yang komunikatif. Adapun, kegunaan modul lainnyaialah sebagai petunjuk mengajar yang efektif bagi pengajar serta sebagai bahan ajar untuk berlatih bagi peserta didik dalam melakukan penilaian sendiri (self assessment). Dengan adanya modul siswa hanya perlu menambahkan catatan-catatan singkat yang mereka peroleh melalui diskusi kelompok. Adapun tujuan penelitian ini adalah untuk meningkatkan hasil belajar siswa dengan menggunakan metode pembelajaran Jigsaw berbantuan modul materi hidrokarbon bagi siswa kelas XI MIPA 1 SMA Negeri 2 Labuapi Kabupaten Lombok Barat.

\section{Metode Penelitian}

Penelitian ini merupakan Penelitian Tindakan Kelas (Classroom Action Research) yang dilaksanakan dalam dua siklus. PTK dilaksanakan dalam proses berdaur (cyclical) yang terdiri dari empat tahapan, planing, action, observation/ evaluation, dan reflection. Teknik pengumpulan data yang digunakan dalam penelitian ini meliputi observasi, wawancara, kajian dokumen, dan tes. Subjek penelitian dalam penelitian ini adalah siswa kelas XI MIPA 1 semester Ganjil SMAN 2 Labuapi tahun ajaran 2020/2021. Pemilihan subjek dalam penelitian ini didasarkan pada pertimbangan bahwa subjek tersebut mempunyai permasalahan teridentifikasi pada saat observasi. Obyek penelitian dalam penelitian ini adalah aktivitas dan hasil belajar siswa.

Data yang diperoleh dalam penelitian ini meliputi data informasi tentang keadaan siswa dilihat dari aspek kualitatif dan kuantitatif. Aspek kualitatif berupa data hasil observasi, angket aktivitas siswa, angket afektif dan wawancara yang menggambarkan proses pembelajaran di kelas dan kesulitan yang dihadapi guru baik dalam menghadapi siswa maupun cara mengajar di kelas. Aspek kuantitatif yang dimaksud adalah berupa data penilaian hasil belajar siswa pada materi pokok hidrokarbon yang meliputi aspek kognitif dan afektif baik siklus I maupun siklus II. Teknik analisis data menggunakan analisis deskriptif kualitatif. Analisis data dalam penelitian ini dilakukan melalui tiga tahap yaitu reduksi data (pengelolaan data), penyajian data (mengorganisasikan data kedalam suatu bentuk tertentu sehingga terlihat bentuk datanya secara lebih utuh), dan triangaulasi atau pemeriksaan keabsahan data dengan memanfaatkan sesuatu yang lain diluar data itu sebagai pembanding data (Moleong, 1996).

\section{Hasil Penelitian dan Pembahasan}

Berdasarkan data observasi, angket, tes dan wawancara yang telah dilakukan selama proses pembelajaran metode Jigsaw berbantuan modul dapat meningkatkan hasil belajar siswa pada materi pokok hidrokarbon. Hasil belajar meliputi aspek kognitif dan afektif. Penilaian aspek afektif dilakukan untuk memberi informasi kepada guru terkait sikap siswa selama proses belajar mengajar. Peningkatan aktivitas belajar siswa disebabkan oleh metode pembelajaran yang diterapkan. Metode pembelajaran Jigsaw memacu siswa untuk aktif 
melakukan kegiatan diskusi, menyampaikan materi yang mereka peroleh, mempresentasikan serta dapat menanggapipresentasi.

Dengan adanya diskusi siswa diberi kesempatan untuk membangun pengetahuan mereka. Selain itu siswa terhindar dari rasa takut untuk bertanya yang sering terjadi apabila pembelajaran berlangsung secara konvensional. Dalam pembelajaran ini guru juga berperan dalam memantau jalannya diskusi setiap kelompok. Guru secara aktif mengunjungi setiap kelompok diskusi untuk menanyakan apakah terdapat kesulitan sehingga siswa merasa lebih dekat terhadap guru yang biasanya hanya berdiri di depan kelas untuk menerangkan. Pada kegiatan presentasi siswa diasah kemampuannya dalam berbicara di depan kelas, sedangkan siswa lain dilatih untuk dapat menanggapinya. Dengan demikian peran guru sebagai fasilitator dilakukan dengan memberi penegasan sehingga persepsi setiap siswa terhadap suatu materi sama dan tepat. Selain itu modul sangat bermanfaat bagi siswa karena dapat digunakan sebagai sumber materi pada kegiatan diskusi.

Pada pelaksanaan tindakan pada siklus II anggota kelompok dibuat lebih heterogen agar siswa dengan kemampuan akademik lebih tinggi dapat tersebar merata ke seluruh kelompok. Pembagian kelompok pada siklus II didasarkan pada perolehan nilai tes kognitif siklus I. Pelaksanaan proses pembelajaran pada siswa lebih ditekankan pada bagaimana siswa dapat memahami materi dengan baik dengan cara menambah latihan soal yang bersumber pada modul yang sebelumnya juga menjadi sumber belajar. Guru juga lebih memperhatikan siswa-siswa yang memperoleh nilai rendah agar siswa tersebut tidak mengalami kesulitan belajar. Selain itu guru juga memacu semangat siswa untuk menyampaikan pendapat dan mau bertanya jika ada materi yang belum dipahami.

Penilaian hasil belajar kognitif pada materi pokok hidrokarbon dilakukan dua kali, yaitu di akhir siklus I dan siklus II. Tes kognitif yang diberikan berupa 15 soal pilihan ganda. Histogram persentase ketuntasan belajar siklus I dan siklus II ditunjukkan pada histogram berikutt

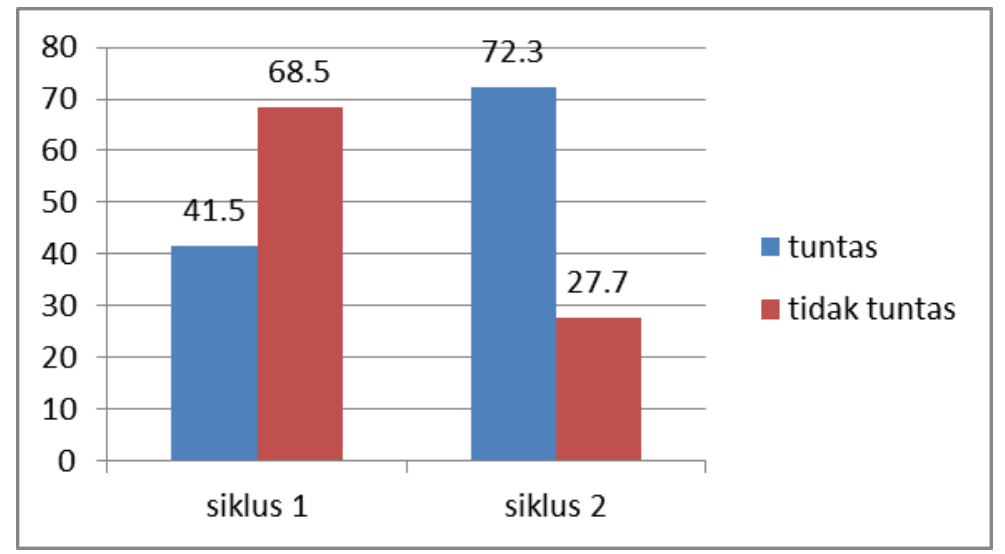

\section{Gambar 1. Histogram prosentase ketuntasan pada siklus 1 dan 2}

Berdasarkan data pada Gambar 2, persentase siswa yang tuntas mengalami peningkatan dari 41,5\% menjadi $72,3 \%$ pada siklus II. Hal ini menunjukkan bahwa pembelajaran Jigsaw berbantuan modul dapat meningkatkan hasil belajar kognitif pada materi pokok hidrokarbon. Pada siklus I persentase siswa yang tuntas belum mencapai target yang diinginkan, yaitu $70 \%$, sehingga perlu dilakukan tindakan siklus II. Peningkatan hasil pada siklus II yang mencapai $72,3 \%$ artinya sudah mencapai target. Hal ini disebabkan pembagian kelompok yang lebih heterogen memungkinkan siswa yang kurang pandai mendapatkan pengetahuan yang lebih dari siswa dengan kemampuan akademik yang lebih baik. 
Pada aspek afektif penilaian diperoleh berdasarkan angket afektif dan lembar observasi. Penilaian ini digunakan untuk memberi informasi terkait sikap siswa selama mengikuti proses belajar mengajar yang meliputi sikap, minat, konsep diri, nilai dan moral. Hasil capaian aspek afektf siswa yang diukur berdasarkan angket yang diberikan pada akhir siklus I dan II serta lembar observasi disajikan dalam histogram berikut.

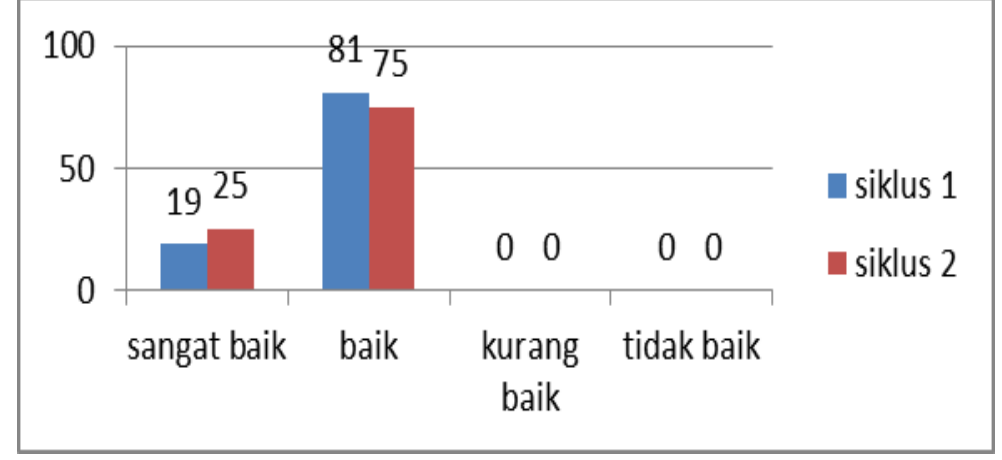

Gambar 2. Histogram prosentase pencapaian hasil belajar efektif pada siklus 1 dan 2

Berdasarkan Gambar 2 diatas menunjukkan terjadinya peningkatan kategori sangat baik dari siklus I ke siklus II. Pada siklus I siswa dengan kategori sangat baik sebanyak 19\% sedangkan pada siklus II mengalami peningkatan menjadi $25 \%$. Secara keseluruhan terjadi peningkatan nilai afektif yaitu $68,92 \%$ pada siklus 1 meningkat menjadi $77,56 \%$ pada siklus II. Berdasarkan hasil observasi dan wawancara merepresentasikan hasil yang sinkron, yang artinya tidak ada perbedaan yang cukup signifikan antara hasil angket dengan kenyataan dilapangan.

Dalam penelitian tindakan kelas, penelitian dapat dinyatakan berhasil apabila masingmasing aspek yang diukur telah mencapai target yang telah ditetapkan. Penelitian ini dapat disimpulkan berhasil karena aspek aktivitas, kognitif, dan afektif yang diukur telah mencapai target. Berdasarkan hasil penelitian yang telah dilakukan dapat disimpulkan bahwa metode pembelajaran Jigsaw berbantuan modul dapat meningkatkan hasil belajar kognitif siswa pada aspek $41,5 \%$ pada siklus I menjadi $72,3 \%$ pada siklus II dan aspek afektif dengan kategori sangat baik $29,4 \%$ pada siklus I dan $70,8 \%$ pada siklus II dan kategori baik sebesar $42,4 \%$ pada siklus I dan 67,6\% pada siklus II pada materi pokok hidrokarbon.

\section{Kesimpulan dan Saran}

Berdasarkan hasil penelitian yang telah dilakukan dapat disimpulkan bahwa pembelajaran Jigsaw berbantuan modul dapat meningkatkan hasil belajar siswa pada materi pokok hidrokarbon siswa kelas XI MIPA 1 SMAN 2 Labuapi tahun ajaran 2020/2021. Berdasarkan hasil dari penelitian yang telah dilakukan, maka dapat dikemukakan beberapa saran yaitu bagi peneliti yang akan melakukan penelitian tindakan kelas selanjutnya hendaknya melakukan kegiatan observasi awal dengan cermat supaya dapat menganalisis permasalahan dan menerapkan solusi yang tepat untuk dilaksanakan. Selain itu bagi guru yang akan melaksanakan penelitian tindakan kelas hendaknya mengerti dengan benar tahaptahap dari metode pembelajaran yang dipilih sehingga pada pelaksanaannya seluruh rangkaian proses pembelajaran dapat berlangsung optimal. 


\section{Daftar Pustaka}

Asni, H. (2017). Upaya Meningkatkan Aktivitas dan Hasil Belajar Peserta Didik Melalui Penerapan Pendekatan Cooperative Learning Tipe Jigsaw di Kelas III-A SD Negeri 2 Cakrangeara. Jurnal Kependidikan: Jurnal Hasil Penelitian dan Kajian Kepustakaan di Bidang Pendidikan, Pengajaran dan Pembelajaran, 3(2). doi:https://doi.org/10.33394/jk.v3i2.567

Fajuri, F. (2019). Penerapan Pendekatan Cooperative Learning Tipe Jigsaw dalam Upaya Meningkatkan Aktivitas dan Hasil Belajar Peserta Didik Kelas I SD Negeri 27 Ampenan. Jurnal Paedagogy, 6(1), 20-26. doi:https://doi.org/10.33394/jp.v6i1.2526

Kusuma, Wijaya. (2010). Mengenal Penelitian Tindakan Kelas. Jakarta : PT. Indeks

Haetami, A., Supriyadi. (2010). Penerapan Model Pembelajaran Kooperatif Tipe Jigsaw untuk Meningkatkan Aktivitas dan Hasil Belajar Siswa pada Materi Kelarutan dan Hasil Kali Kelarutan. Jurnal WAKAPENDIK. 6 (1) 1-11.

Munadi, Y. (2010). Media Pembelajaran. Jakarta: Gaung

Moleong, (1996). Metodologi Penelitian Kualitatif . Bandung: Remaja Rosdakarya.

Mustamiin, M. (2016). PENGARUH PENGGUNAAN MODEL KOOPERATIF LEARNING TIPE JIGSAW TERHADAP HASIL BELAJAR IPS DI TINJAU DARI MOTIVASI BERPRETASI. Jurnal Teknologi Pendidikan, 1(2), 65-76. Retrieved from http://ojs.ikipmataram.ac.id/index.php/jtp/article/view/612

Nashirotun, B. (2020). Peningkatan Aktivitas dan Hasil Belajar Siswa dengan Metode Jigsaw dan Media Tubuh Manusia pada Pembelajaran IPA di MTs. Negeri 4 Klaten Jawa Tengah. Jurnal Paedagogy, 7(4), 402-407. doi:https://doi.org/10.33394/jp.v7i4.2945

Nirta, I. (2019). Upaya Meningkatkan Aktivitas dan Hasil Belajar Peserta Didik Kelas IV SD Negeri 14 Cakranegara Melalui Penerapan Pendekatan Cooperative Learning Tipe Jigsaw. Jurnal Paedagogy, 6(1), 8-13. doi:https://doi.org/10.33394/jp.v6i1.2524

Prastowo, Andi. (2014). Pengembangan Bahan Ajar Tematik.Jakarta: Kencana

Pratini, P. (2015). Upaya Meningkatkan Aktivitas dan Hasil Belajar PKn Siswa Kelas VIII-B SMPN 18 Mataram Melalui Penerapan Pendekatan Cooperative Learning Tipe Jigsaw. Jurnal Kependidikan: Jurnal Hasil Penelitian dan Kajian Kepustakaan di Bidang Pendidikan, Pengajaran dan Pembelajaran, 1(2). doi:https://doi.org/10.33394/jk.v1i2.417

Sagala, Syaiful. (2009). Konsep dan Makna Pembelajaran. Bandung: Alfabeta

Wulandari, W., \& Sakti, H. (2020). PENGARUH MODEL PEMBELAJARAN JIGSAW TERHADAP MOTIVASI BELAJAR SISWA. Jurnal Teknologi Pendidikan, 4(1), 70-77. Retrieved from http://ojs.ikipmataram.ac.id/index.php/jtp/article/view/2260 